\title{
$[\mathrm{CN}] 2$
}

\section{[CT] Sexuality and Politics: Lady Morgan and the Morality of the Italians}

Roberto Bizzocchi

\section{[A] Lady Morgan, Sismondi and Cicisbeism}

If pressed to say which writer most interested and preoccupied Italian intellectuals of the first half of the nineteenth century and beyond, I would have no hesitation in naming Jean-LouisCharles Simonde de Sismondi, and in referring in particular to the final volume of his Histoire des Républiques italiennes du Moyen Age. In 1819, a year after the publication of this volume, Alessandro Manzoni responded with his Osservazioni sulla morale cattolica (Observations on Catholic Morality). A few years later, the very real impact of Sismondi's volume could also be discerned in Giacomo Leopardi's Discorso sopra lo stato presente del costume degl'italiani (Discourse on the Present State of the Customs of the Italians, 1824) and still more so in a crucially important essay written in 1826 by Ugo Foscolo during his English exile, namely, 'The Women of Italy'. Yet again, following the attainment of Italian unity, the great literary critic, patriot and Minister of Education Francesco de Sanctis could write that the Histoire 'should be our code, our gospel, until we rebuild our character': ${ }^{1}$ a judgement which, after all, perfectly corresponds with the essentially 'Sismondian' approach adopted by De Sanctis when drafting his masterpiece, the Storia della letteratura italiana. If Sismondi serves as my point of departure here, it is because Lady Morgan's account of Italy, though founded upon personal experience and though containing some other, original observations of real interest, elaborated upon below, obviously owed much to the work of the Swiss historian. I will begin by rehearsing the essential points of the last volume of the Histoire, in which Sismondi, going beyond the chronological limits indicated by the general title of his vast work, deals with Italian history in the early modern period. In his view, after 
the glorious age of the free Communes, Italy entered a phase of profound political and moral decadence. The decision to highlight one episode as a symbolic crux - the fall in 1530 of the so-called Last Florentine Republic - clearly indicates what Sismondi considered to be the causes of this decadence, namely, the end of political independence with the consolidation of Spanish rule, and the incipient stifling of autonomy and intellectual creativity under the looming Counter-Reformation.

There is one aspect of this celebrated, endlessly reiterated and debated 'Sismondi thesis' that has not always been accorded the attention it deserves. I refer here to the marked emphasis upon and the forthright condemnation of the private morality and lifestyle of Italian men and women, particularly their sexual habits and practices. The chaste Manzoni, the yet more chaste De Sanctis and the inexperienced Leopardi passed over this subject, but the highly experienced Foscolo chose rather to put it at the heart of his article about Italian women, and with good reason. In actual fact, Sismondi deemed sexual morality to be so important that he saw it as the main cause of Italian decadence, a decadence, it should be noted, that pervaded every sphere, including general politics. His bete noire was the cicisbeo (also called, more respectfully, cavalier servente or lady's escort), a figure who, according to long-established custom in Italy, appeared in polite society at the side of a noblewoman, though not her husband, as friend and escort. We are concerned here, in other words, with the character who, apart from enlivening social occasions in eighteenth-century Italian cities, featured as the protagonist in many of the literary masterpieces of the century, including Giuseppe Parini's long poem Il Giorno, which recounts a day in the life of a cicisbeo, and many of Carlo Goldoni’s comedies.

Very controversially asserting the right of foreigners to be astounded by so perplexing an example of moral corruption, Sismondi defined cicisbeism as a 'public calamity' which was at the same time 'perhaps the most general cause of the private woes of all Italian 
families'. He advanced a frankly political interpretation of the custom, which he viewed as a device for 'easing the fretful spirits recently reduced to servitude', and one that confirmed, in short, through the ingrained habit of frivolity and duplicity, the fawning compliance of the Italian ruling classes deprived of their independence and freedom. Delivering a wholly negative judgement on a fashionable sociability that did not revolve around encounters between pairs of married couples, Sismondi concluded with a dramatic account of the impact of cicisbeism upon matrimony and upon routine domestic life in Italy:

[EXT] No husband could any longer look upon his spouse as a life-long faithful companion; no longer could he find in her a counsellor in his doubt, a support in adversity, a saviour in danger, a comfort in despair; no father would dare to assume that the children of his marriage were really his. [In conclusion] not because some women had lovers, but rather because a woman could no longer appear in public without a lover, the Italians ceased to be men. ${ }^{2}$ [EXT ENDS] A bizarre inconsistency in Sismondi's account helps to highlight the markedly political character of his moral condemnation. In fact, this extremely harsh treatment of cicisbeism, exaggerated almost to the point of caricature, is all the more noteworthy for its not appearing at the beginning of the chapter on the eighteenth century, the period when the custom had actually flourished, but rather at the beginning of the chapter on the seventeenth century. Obviously, at the height of the Counter-Reformation, there had been no cicisbei, but Sismondi deliberately handled his material anachronistically in order to underline how Spanish Catholic rule had been the cause of the corrosion of the moral and intellectual fibre of the Italians, who were by then but a pale shadow of their ancestors from the age of the free Communes.

I will shortly turn my attention to Lady Morgan, but first I should say something more about Sismondi, whose influence upon the celebrated Irish author was, as I remarked above, 
very great, even though she would subsequently develop some important lines of thought of her own. I have already noted how Sismondi inspired a major debate during the Risorgimento, because all the Italian intellectuals preoccupied by the question of national rebirth had no choice but to come to terms with his idea about the relationship between political servitude, public decadence and private immorality. The publicist from Geneva did, however, also represent the culmination of the travel literature of the Grand Tour, an enormous mass of eye-witness accounts, letters, diaries and correspondence, which taken as a whole had a decisive role to play in preparing the crystallisation of the image of Italy and of the Italians conveyed to European culture by the greatest Romantic intellectuals: even earlier than Sismondi, his friend Madame de Staël, with her novel Corinne, ou de l'Italie (1807), exerted a profound and far-reaching influence, not least upon Sismondi himself. ${ }^{3}$ In the texts of the Grand Tour, as in travel literature in general, we find a bit of everything: useful information, astute observations, idle chatter, turgid plagiarism, utter nonsense and sometimes even outright slander. In any case, such texts usually tell us more about the travellers' own culture and outlook than about the reality of eighteenth-century Italy; besides, as a whole, they ended up constructing, as the most thorough study of the subject - one informed by a deep knowledge of eighteenth-century history - has shown, a predominantly negative image. ${ }^{4}$

As it happens, the private immorality, especially in its sexual aspects, of Italian men and women was one of the main components of this negative image, often underlined in a somewhat obsessive way, by turns scandalised and prurient. It was in the eighteenth-century writings of the Grand Tour that Italian marriage, and hence cicisbeism, began to be accorded the treatment that would later be elaborated upon, at another level of seriousness and commitment, in Sismondi's Histoire. ${ }^{5}$ And it should immediately be pointed out that the treatment suffered almost invariably - the very few exceptions were mainly due to French 
travellers, less ignorant of the Italian language and better acquainted with the milieux in question - from a fundamental flaw, a misunderstanding with the gravest of consequences. Indeed, though Grand Tour literature had lavished oceans of ink on cicisbeism, it had committed the signal error of treating as an erotic practice what in fact was a social institution.

Without exploring this subject in depth here, I will nonetheless recall at least some fundamental aspects so as to bring out the superficial and reductive nature of the image conveyed by Sismondi and the travellers on the Grand Tour. These aspects appear clearly if, in studying the phenomenon, we consider not only sources such as travel narratives, comedies and literary satires, but also the private documents of the men and women of the Italian eighteenth century, their diaries and letters, as well as the matrimonial lawsuits in which they were sometimes embroiled. First of all, cicisbeism was a way of introducing women to the new Enlightenment sociability, which was far more open than the sociability of the age of the Counter-Reformation had been: in the seventeenth century, women mainly attended parties and social gatherings essentially confined to their immediate families or to a wider circle of relatives. The greater freedom that characterised eighteenth-century social relations sometimes allowed, and in certain cases required, women to meet strangers. In this regard, the role of the lady's escort was one of mediation, but also of protection and surveillance - in other words, much the same role as a husband would have played. It is necessary to set aside moralistic prejudices and to try to grasp the reasons why husbands should have been flanked and often replaced by cicisbei when women were escorted to social events. There might well be love and affection in a marriage under the ancien régime, but it was not based, as at least in theory it would be in the nineteenth century, on a total sharing of life or, rather, on reducing a wife to being a part of her husband's family and a social appendage. On the other hand, the hereditary practices of the aristocracy, founded upon 
entailments and primogeniture, produced a great number of young men and women destined never to marry. The latter were mainly dispatched to convents, but many of the young men continued to live in society, with little or no prospect of forming a stable couple or starting a family of their own. It was taken for granted that they would satisfy their sexual urges with lower-class women, but there was obviously the greatest concern lest they fall in love with these same women and even go so far as to insist on marrying them. From this perspective, the position of friend and escort to a woman of their own class and education could act as something of a deterrent to these young men, a kind of disciplined socialising in the fashionable world and a well-regulated sentimental education, liable to keep the mind occupied without inflaming it.

Naturally, escorts and the ladies they served did not usually choose one another: the elderly male heads of families who forged matrimonial alliances also decided who the third element in the triangle should be. It can readily be imagined - and it can in fact be documented - that this choice was usually made on the basis of a prudent evaluation of the personality of the young man, who was expected to perform a strictly Platonic role in the triangle. The entire negotiation had a significance which it would be no exaggeration to describe as political, since it constituted a further strand of alliance, in addition to the matrimonial one, between families from the aristocratic ruling classes. This is particularly evident in the case of the 'republican' cities, those which still continued to govern themselves without a prince, like Venice, Genoa and Lucca, and also in those, like Milan or Florence, where city traditions - a profound sense of civic culture and pride - remained very strong even under the rule, respectively, of the Habsburgs and the Lorraine, and in the presence of sovereign courts which influenced aristocratic sociability. In these cities, the intertwined relationships between husbands, wives and ladies' escorts were a kind of consolidation of the alliances between families and groups active in the political arena. 
Furthermore, it should be borne in mind that the relationship between a lady and her cicisbeo was obviously not clandestine and did not unfold in the shadows, but openly and publicly, and in accordance with very precise customs and rules, of an almost ceremonial character, which tended to inhibit and preclude any sexual implications, even after and notwithstanding the above-mentioned shrewd choice of the young man in question. We do not have to think the very worst of the protagonists to suppose that from time to time, such implications would in any case have been realised. Indeed, a number of sexual relationships between ladies and cicisbei are unequivocally documented in the historical sources of a civilisation which practised gallantry less neurotically than the civilisations that preceded and succeeded it. But on this basis, to maintain, as Sismondi, following in the footsteps of the travellers on the Grand Tour, was prepared to do, that each and every lady was having an affair with her escort, and even that all these ladies' children were of doubtful paternity, is not only a falsehood, it is also, to put it bluntly, patent nonsense.

It should also be stressed that cicisbeism was not at all an exclusively Italian phenomenon; if anything, it was an exclusively Catholic one, being very well documented in, for example, Spain. We should certainly not neglect the fact that in Calvinist or Lutheran countries, the combination of compromises upon which the custom rested was not widespread and was perhaps not even conceivable. In actual fact, the custom's tortuous coexistence with the theory of Catholic morality, and with the practice of the latter in the confessional, constitutes one of the most complex and interesting aspects of its history. In any case, its existence outside Italy serves to discredit the Sismondian idea that the conjugal and sexual immorality of the Italians was the cause of or a factor contributing to an unabashedly servile political subordination..$^{6}$

All things considered, the truly salient feature of cicisbeism - the aspect that should especially be borne in mind in connection with Lady Morgan, though other elements are also 
important - is its inseparable link with eighteenth-century Enlightenment and aristocratic sensibility. On the one hand, the custom is not even imaginable before the establishment of the cultural attitudes and the practices of the fashionable life of the Enlightenment. On the other hand, it could not survive the concentric attack of the two great phenomena which, at the turn of the eighteenth century, sealed the fate of the ancien régime, namely, Romanticism and the French Revolution. As to why cicisbeism was incompatible with the Rousseauesque ideal of conjugal love looming over the bourgeois European nineteenth century, there is really no need to labour the point. However, this same custom was by then also unacceptable from a strictly political perspective, since it meshed - as I have already noted - with the systems of solidarity and alliance-building between the ruling families and castes of the various Italian cities, namely, the urban aristocracies, which were more or less enlightened but which were in any case much preoccupied by their identity as elites that excluded those who did not belong by birth to the nobility.

In fact, with the arrival of the French in Italy, cicisbeism came to a somewhat abrupt end. Even setting aside all the 'Spartan' ideology of the irreproachable and unsullied republican woman vaunted in the propaganda of the Revolution, what was of decisive importance was the simple fact that the French obliged the Italian nobles to adopt a form of social life open to the families of the bourgeois notables. In this new situation, the nobles themselves refused to continue employing that useful but finely balanced arrangement of husband, wife and cicisbeo, a triangle unacceptable outside of pre-Revolutionary aristocratic sociability, which had been relatively open-minded but also highly formal and subject to strict rules of etiquette. Among the many relevant testimonies, I will simply recall the crucial diary of Luisa Palma Mansi, a noblewoman from Lucca with a lively intelligence and a strong personality who kept a very detailed record of her society life in the 1790s when accompanied by her escort Costantino de' Nobili, and then an equally precise analysis of the 
end of a world, swept away by the arrival of the French and never to flourish again, not even at the Restoration. Up until the fall of the Republic of Lucca in 1799, Luisa Palma had invariably been at the very heart of the city's fashionable life, but once all the balls and parties, in accordance with the wishes of the new French rulers, had been thrown open to men and women not of the nobility, she actually endeavoured to avoid them. This she could not do, since her husband, too prominent to be able to adopt even tacitly controversial attitudes, would not permit it, but she tried nonetheless to keep a low profile and was very quick to realise the inappropriateness of continuing to have a cicisbeo. ${ }^{7}$

So too where the chronology of cicisbeism is concerned, a comparison between the accounts of travellers, particularly if they were foreigners, and the documents produced by the Italian protagonists of matrimonial and family life between the 1700s and 1800s is highly instructive. It is within this framework that we can appreciate the value and the intrinsic interest of Lady Morgan's intervention. There are also travellers' accounts dating back to the early years or decades of the Restoration, which continue to describe the private morality and erotic habits of the Italians under the heading of an (alleged) depravity typified by cicisbeism. In certain cases, such descriptions may perhaps represent lingering traces or even a late flowering of the custom, usually in very peripheral areas, or specifically in Sicily, which neither the French nor their revolutionary morality had reached. ${ }^{8}$ But for the rest, it is a question of stale repetitions of the old topos of the literature of the Grand Tour, which tell us nothing of how things really were, and are comprehensively refuted by the first-hand accounts we have on the subject. Naturally, the end of French rule had, to a certain extent, breathed new life into the habits and inclinations of the old aristocrats who had been raised and educated before the Revolution or, more precisely, before its importation into Italy, starting in 1796, but it was in fact a residual phenomenon. The Restoration - I do not think it 
necessary to labour the point - did not bring back the society of the ancien régime, or therefore its forms of private life or its matrimonial model.

In time, the contrast, at any rate so far as Western Europe was concerned, between the customs of the eighteenth century and those of the nineteenth century would come to seem obvious and clear-cut: suffice it to mention the very effective short story Jadis (1880), in which Guy de Maupassant gives it an existential emphasis in the moving dialogue between a gallant (and politically reactionary) old grandmother and her romantic and earnest young granddaughter on the subject of love. Lady Morgan's main and outstanding merit, in relation to Italy, is that she opportunely grasped this crucial aspect, testifying with scruple and sensitivity to the great transformation in the morality of the Italians during the critical transition from the ancien régime to the Revolutionary Age and then the Restoration. Her gaze is, for us, as valuable as it is rare: all the great men who - as we have noted - in one way or another, like her, addressed the issue of Italian moral corruption disappoint us, for various reasons, when it comes to the crucial question of the changes in sexual and matrimonial life and the end of cicisbeism. Sismondi still remained entangled in, and influenced by, the misinterpretations conveyed to him by eighteenth-century travel literature. In 1826, Foscolo wrote incongruously of how the customs of Italian women had been harmed by bachelorhood and cicisbeism as if it were still a current and pressing problem, but he had been in exile in England for ten years and this painful separation weighed very heavily on his otherwise astute judgement. ${ }^{9}$ Manzoni and Leopardi simply do not consider the problem, thus implicitly dismissing it as irrelevant and outdated. After all, the former, who was the grandson of Cesare Beccaria and Pietro Verri, and the illegitimate son of a pious old woman with a turbulent past, strikingly exemplified in his private and married life a rapid, even abrupt detachment from the practices of eighteenth-century gallantry. ${ }^{10}$ 
Lady Morgan, for her part, tackled the issue head-on; indeed, she could almost be said to have made it one of the guiding threads of her long and impressive book about Italy. There is nothing untoward about this fact, given that she travelled in the peninsula with her husband, the English doctor Thomas Charles Morgan (she herself, Sydney Owenson, was Irish, then about 40 years old) in 1819-20, having just read the final volume of Sismondi's Histoire, in which the corruption of Italian marriage stood out as the primary cause of the country's decadence. The general framework of Sismondi's interpretation of Italian history obviously influenced Lady Morgan's ideas and the typically anti-Catholic stamp of her straightforward political liberalism. Anything but a fanatic in professing her Protestant faith, she was however inclined to underline the harm wrought by the influence of Catholicism in private and public life. Nevertheless, she had managed to travel through Italy without blinkers, proving herself to be not only a friendly and well-disposed observer, but also one capable of translating such feelings into a form of moral acceptance and therefore of understanding.

In this regard, it is worth recalling a judgement about Lady Morgan as a traveller, even before considering her merits as a writer, offered by an Italian, Federico Confalonieri, a man of the world and one not averse to venting his scorn if the need should arise. In his letter of 4 July 1819 to Gino Capponi, there is certainly a hint of condescension towards the English lady's maladroitness, but he frankly acknowledged her positive qualities: 'She is a wonderful woman, but if truth be told, I do not have a high opinion of her judgement and her tact, and I have a better one of her wit, and mainly of her heart.' This is a description which, despite its caveats, nevertheless bears witness to the sympathy and wide-ranging understanding with which Lady Morgan, unlike so many other travellers, had viewed the places and people she had visited and encountered. Confalonieri's judgement was in fact later by and large borne out by Capponi himself after he had read Italy, or rather L'Italie, which 
seemed to him, despite its many naive remarks and minor errors, based on sound information derived from a real and genuine interest in the subject: 'After all it is written with wit, accurate observations, and a great deal of knowledge of our customs, and of our recent history, public and private; which she clearly gathered from people who knew the country well, especially in Milan and Florence.' ${ }^{11}$

\section{[B] Italy seen through the eyes of an impassioned observer}

As I have just noted, Lady Morgan’s book about Italy was not available to Italian readers in the original English text of 1821, but in the French version translated in Paris that same year and published in four volumes. In Italy at that time, almost no man of letters could read English, while many read French. In an article such as this one, concerned with the relationship between travel narratives, their Italian reception and the contemporary Italian situation, it is therefore appropriate to quote from Italy in its French version which, faithful to the original, although not always perfectly so, did in fact represent Lady Morgan's contribution to nineteenth-century Italian culture. The passages as they were in the French edition are therefore given in the footnotes. ${ }^{12}$

Apart from the medical-statistical appendices written by Charles Morgan, the material is arranged city by city, retracing the couple's itinerary, but the main body of the text is preceded by a historical introduction which steers the reader towards a kind of examination of the 'Sismondi thesis'. A striking confirmation of its central significance is the role played, in the historical introduction, by the final defence of the Republic of Florence in 1530: the concluding judgement on the episode - 'Italy fell with Florence'13 - leaves us in no doubt whatsoever as to the Sismondian affiliation of Lady Morgan. Moreover, a little further on, she explains that she had felt impelled to go back in time in order to reveal the exemplary history 'of the Italian Republics', namely Sismondi's medieval Communes, which were 
worthy to stand comparison with free British institutions. ${ }^{14}$ In the rest of the work, the section in which the impact of Sismondi's idea about the decadence of modern Italy is most in evidence is, understandably, the one dealing with Rome, which, among other things, also appears to be the one most burdened with negative stereotypes deriving from the literature of the Grand Tour. Papist Catholicism, Lady Morgan declares, has made the city's religious and secular condition 'an anomaly in human society' $;{ }^{15}$ corruption has reached unimaginable levels; the womenfolk are tainted by the presence of a lecherous clerical class; only in the middle class can one discern a glimmer of redemption, while the nobles are 'foul and fatuous as an Indian fakeer [faquir], and sunk in the dusky niche of its splendid sty' ${ }^{16}$

I have no hesitation in defining a page such as this, along with a few others in the book, a false note on Lady Morgan's part. Obviously, it was her progressive liberalism that served to reinforce the conviction, traditional among the British travelling in Italy, of the unrivalled excellence of the British way of life: a simply unattainable model for the Italians, according to the more ill-disposed visitors, or to be pursued by every possible means, according to those with a kindlier view of Italy. Here and there, in Italy, there are traces of this by then venerable superiority complex (dating back to the religious wars of the sixteenth century). ${ }^{17}$ But what saved Lady Morgan from the paralysing consequences of banal prejudices was the fact that her thought was firmly anchored to a serious political anthropology, one incompatible with any superficial ethnic-naturalistic approach. Her noble indignation when she recalls Nelson's betrayal, at the urging of Lady Hamilton, of the Neapolitan patriots in 1799 comes from a mind capable of overcoming stereotypes: there is no conduct that is of itself Italian or English, but merely liberal or reactionary, loyal or abominable:

[EXT] When the author of these pages was too young or too ignorant to interest herself in the political transactions of any country, she had listened with admiration to Lady n 14 (1) don't match style in n 13 (I) - which is correct?
Comment: QUERY 3: In defining in a page? Sentence reads as if somewhat incomplete at present 
Hamilton, as she described to her the beauties of the shores of Naples, and her own distinguished position, when, during the calm of many a moonlight night, she had sat in the English admiral's ship, on the right of the Hero of the Nile, and sung over the waves of the Mediterranean the national hymn of Rule Britannia, which was chorussed by the whole crew: but had her auditress known that while the Syren sang, thousands perished, and that these nights of revelry closed days of blood, she would have fled the voice of the charmer, as she now (and more particularly since her visit to Naples) holds her memory in utter abhorrence. Let those who rejoice in the defeat of the Neapolitan patriots of 1821 , remember the fate of those who were exposed to the royal clemency of Ferdinand the Fourth, in $1799 .{ }^{18}$ [EXT ENDS]

After all, apart from the section about Rome - which is somewhat overstated, flat in tone and wholly lacking any sense of historical perspective - Lady Morgan's approach is in fact characterised by a marked tendency to understand and describe differences and changes. In Milan above all, of course, but to a certain extent everywhere in Italy, she was able to perceive the rapid and sustained development of a new culture and a new political consciousness. Her warm praise of Il conciliatore, which had just been suppressed after an all too brief existence, indicates her perspicacity: 'within that short compass, it has contrived to disseminate a greater quantity perhaps of literary and philosophical truth, than will be found in any contemporary journal that has appeared since the Restoration'. ${ }^{19}$ We cannot help but admire the timely fashion in which she equates cultural innovation and political liberalism, Romanticism and freedom - an equation which was increasingly valid in the Italy of the Restoration, and particularly in the Milan of Manzoni, as well as of Il conciliatore, but was certainly not to be taken for granted in Europe.

The dominant feature of Italy is its consistently diachronic perspective, and with it an acute political awareness of the positive epoch-changing function of French rule, which had 
inspired in the country's new ruling classes a by then irreversible progress in society. Lady Morgan astutely grasped the existence of an unbridgeable generation gap in the outlook of the Italians. The argument, stated in the section dealing with Milan, is variously repeated in other parts of the book:

[EXT] The abolition of all monastic institutions, the reformation of the universities, the establishment of female schools, the military conscription, and the great political convulsions of the last twenty-five years, stamped a new impress upon the rising generation, and drew a line of demarcation between the sons and their parents, which it is impossible to efface. ${ }^{20}$ [EXT ENDS]

Thanks to the fact that her views were firmly rooted in political reality and its consequences for everyday life, Lady Morgan manages, in the course of the work, to free herself from a too servile dependence on Sismondi's approach, even though she herself had in fact adopted it, at the beginning of the book, as her own interpretative key to understanding Italian history. In contrast to the travellers on the Grand Tour, Sismondi had had the merit of overcoming every trace of an abstractly naturalistic evaluation - or rather devaluation - of the Italian character, closely linking the problem of decadence to the country's political and religious history. He had, however, evaded the new question posed by the effects of the Revolution and French rule in Italy. The concluding chapter of the final volume of the Histoire, the one in which he explicitly draws his conclusions about the Causes qui ont changé le caractère des Italiens, depuis l'asservissement de leurs Républiques ('The Causes which have changed the Character of the Italians following the Foreign Subjection of their Republics') presents the link between Catholicism, the corruption of private customs and political servitude as an immutable fact, almost without any distinction between the sixteenth century of the Council of Trent and the eighteenth century of enlightened reforms, and in any case only making a couple of allusions to the moral redemption underway in Italy in the early nineteenth century. 
Compared to her master, Lady Morgan shows herself to be, only a few years later, up to date and more consistent in her efforts to reconstruct the interaction between politics and morality. A great number of pages from Italy do indeed deal with the morality of the Italians, and it is in these pages that Lady Morgan offers her most original and interesting contribution to the discussion of matrimonial corruption and cicisbeism, phenomena that eighteenth-century travellers and Sismondi alike had seen as the central aspect of Italian society and the most glaring symbol of the Italians' (tarnished) image in Europe. Obviously, one cannot expect Lady Morgan to have been able to appreciate the historical significance of cicisbeism in the context of the matrimonial model of the Italian aristocracy of the ancien régime and in the framework of eighteenth-century European gallantry: her adherence to the ideal of conjugal domesticity promoted by Rousseau led her to judge Italian family life in terms of its correspondence or otherwise with that ideal, in particular with the version which over the previous few decades had been so rapidly consolidated in the British sphere. Nevertheless, or perhaps precisely on account of this, she noted with evident fondness and an unfeigned admiration the clear signs of adaptation to the new lifestyle on the part of the Italian elites with whom she came into contact during her travels in Italy.

Lady Morgan also encountered examples of the force of inertia of the old customs, in part rehabilitated after the defeat of the political revolution, but she was able - in contrast with what had been and still was the case in most travel literature - to see them for what they were in the context of the development of Italian civilisation: minute traces, which certainly did not represent the alleged, unhistorical and natural character of the Italians. As I have already observed, in the eighteenth century, the role of lady's escort, when viewed in the context of Enlightenment sociability, had not of itself led to any particularly backwardlooking stance: after all it had been practised by, among others, Pietro Verri and Vittorio Alfieri, even if both had criticised its affected nature. But in 1819 and 1820, around 60 years 
after the first publication of Rousseau's main works and in the light of what had happened in Europe in the preceding three decades, any intention to perpetuate or rekindle the customs of gallant marriage and cicisbeism seemed to wreak of a nostalgia inevitably imbued with a reactionary political ideology.

This absolutely crucial point is highlighted by Lady Morgan with incomparable clarity and wit: here and there throughout Italy, but particularly in the pages dealing with Florence, Milan, Genoa and Naples. In the Tuscan capital, where in her view there was also, as elsewhere, between the young and the old 'a moral distance greater than the lapse of ages have hitherto produced', ${ }^{21}$ the phenomenon of cicisbeism seemed, to her, to survive with a little less difficulty because of the excessive influence still wielded by the Catholic religion through the convents on girls' education; nevertheless, she concluded, the custom was 'by no means universal even there'. ${ }^{22}$ As for Milan, Carlo Porta's admirers will relish the description in L'Italie of the only place where by that date the 'ancien cavalier servente' has taken refuge, namely, the salons of the reactionary damazze del biscottin ('the great ladies of the little biscuits'), the same dowagers who support in their entourage the famished and servile family priests immortalised in La nomina del cappellan, one of Porta's masterpieces, whose great popularity in the city is underlined by Lady Morgan, even though she does not mention the author by name. ${ }^{23}$

Lady Morgan's discussion of the reactionary implications of gallantry is conducted in the most detailed fashion in the pages she devotes to Genoa, which in the eighteenth century had been one of the capitals of cicisbeism, taking her cue from soirées she had attended in the palazzo of the Marquise Pallavicini. Here she had found convincing proof of the improvement in the Italians' domestic customs, thanks to the evidence of an exemplary conjugal and family life: 'no cecisbeo, no patito, no meddling confessor!'. Gallantry had by 
now after all been banned by the Genoese aristocracy, except by those inconsolably yearning for a world that had ended:

[EXT] Still, however, among the old aristocracy, some monumental traces of the genuine Genoese patito, or amatory martyr, may be found, in the remains of the beaux garcons of the Veglia di Quaranta; still carrying the prayer-book, or presenting the bouquet of their liege lady, and accompanying her to the promenade of Strada Nuova in the evening, or to the church of the Annunciata in the morning. But the education presided by Jesuits and Inquisitors, which left the youth of Genoa ignorant and feeble, and threw them on gallantry and gambling for their sole occupation and resource, has long ceased to exist, and has not yet been revived. ${ }^{24}$ [EXT ENDS]

This passage clearly shows the crucial political implications of the renewal of Italian consciousness and the sympathetic promptness with which Lady Morgan was prepared to testify to it. Her angry awareness of, and identification with, an ongoing struggle between liberal civilisation and the superstitious and fanatical spectres of reactionary authoritarianism charge her description of private morality in Italy with a tension that corresponds with her idea of the link between morality and national redemption. This subject is finally restated in the most solemn and impassioned way in the section about Naples, the city which - as we have already seen - provoked very strong self-critical feelings in her about the limits of liberalism and British civilisation. It should be borne in mind that Naples and its inhabitants had been the main targets of the criticisms of the travellers of the Grand Tour: suffice it to mention the notorious Samuel Sharp, the author of Letters from Italy, Describing the Customs and Manners of that Country, who had, basing his case on Naples, produced during his travels of 1765 and 1766 a criticism of Italy which was so scornful as to induce Giuseppe Baretti to publish in English a lengthy, and frankly none too effective, apologia. ${ }^{25}$ 
Lady Morgan certainly did not avert her eyes from the city's atavistic problems and in particular the dramatic conditions of backwardness endured by the masses, but she effected a veritable rupture, and one worth highlighting, in relation to the litany of condemnations and demonisations of the Neapolitan masses, transmitted almost mechanically from traveller to traveller through their written accounts: 'Taking the Neapolitan population as a whole, it possessed sufficient energy and virtue to have produced and maintained a constitutional system, but for the unprincipled interference of foreigners. ${ }^{26}$ And as for the nobles, she judged them in a completely different way from their Roman counterparts. The recollection of the bloody repression of 1799 serves as an introduction to the laudatory portrait of Prince Pignatelli Strongoli, the brother of two of the fallen of the Neapolitan Republic: 'He unites the fine qualities of his brothers to very distinguished political and literary talents; his domestic virtues and habits of life are in unison with his patriotism and public principles. ${ }^{27}$

Domestic virtues, patriotic principles: the confident identification of this unbreakable link constitutes the hallmark of Italy and the greatest merit of its author. In meeting Italian aristocrats, Lady Morgan in fact grasped with humane perspicacity and great timeliness the cultural tendency which had dealt a mortal blow to the matrimonial morality of the ancien régime, including gallantry and cicisbeism: namely, the tendency to identify the reform of the family with national resurrection. I will shortly show, with some concluding remarks, how Lady Morgan was thus attuned to the decisive change that was taking place in the Italian culture of the first half of the nineteenth century, but first I would like to take leave of her fine book at the eloquent and deeply felt page which brings to a close - once again on the subject of private virtue - the peroration on the victims of 1799 and the new repression of the uprisings of 1821:

[EXT] Such are the scenes of domestic virtue to be found in Naples, the result (it cannot too often be repeated) of those institutions which put down monastic orders, and closed 
the cells where youth submitted to incarceration in obedience to that political and religious system, which obliged parents to rend the holiest ties of nature, and sacrificed children to the interests of a sordid ambition ... May the horrors of the royal and imperial re-action stop at the gates that inclose virtues and feelings so mild and so beautiful; and may no Acton or Vanni of the present day, no Ruffo or Canosa, drag to the tribunal or the scaffold the members of those illustrious families, who have again stood foremost in the ranks of patriotism, seeking to redeem their country, and preserve its newly acquired virtues, in despite of that league of invading dictators, to whom virtue is but a name! $!^{28}[$ EXT ENDS]

\section{[B] Italian responses to Lady Morgan}

Pages of this sort were bound to irritate all the reactionaries of Europe, including British conservatives, who greeted Italy $\mid$ with undisguised hostility. The reception accorded to the work by English readers is of great interest and has been the object of a lengthy study furnished with ample documentation. ${ }^{29}$ Here I am more concerned with the impact of Lady Morgan's book upon Italian readers. The most sensational response came from a woman of letters from Ferrara, Ginevra Canonici Fachini, who in 1824 added a reply to L'Italie to her Prospetto biografico (Biographical Survey) of Italian women writers from the fourteenth to the nineteenth centuries. The type of direct confrontation chosen by Ginevra Canonici and the fact that the two protagonists were women has meant that this Italian reply has attracted a great deal of attention, so much so that the Morgan-Canonici comparison has become a kind of historiographic topos. ${ }^{30}$

In fact, the text of the Italian woman of letters is really rather modest, and no more than what we might expect from someone prickly enough to misinterpret a book which was actually an intelligent declaration of love, and poor enough in spirit to want to assume the 
role of a controversialist: what about the morality of English women - Ginevra Canonici insinuated - who, when a guest arrives in their homes, fling their arms around his neck and smother him with kisses? However, her apologia has one noteworthy aspect: the essential confirmation of the ongoing adaptation of the Italian matrimonial model to the Rousseauesque one, now triumphant in Europe, and therefore also of the end of cicisbeism. And from this perspective, it matters little that in her zeal, the Italian author presented as a refutation what was in actual fact a reiteration and amplification of the theses of L'Italie: [EXT] For many years now a husband accompanies his wife everywhere, when affairs of state, the law court, or his own private concerns permit it; nor is a wife then bound by a demeaning slavery, but often alone, or accompanied in a decorous manner, she enjoys those pleasures which are considered useful and necessary for physical and moral wellbeing ... Integrity and honour are our glory, and reasoning like this you will render full justice to my nation. ${ }^{31}$ [EXT ENDS]

After all, the fact that figures such as Confalonieri and Capponi reacted positively to Lady Morgan and her book, as we have seen, confirms that L'Italie was dealing with the crucial point: the political construction of the new Italy had perforce to proceed by way of a preliminary reconstruction of the moral character of the Italians, starting with their intimate lives and sexual practices.

An era - and with it the themes, the motifs, indeed, the actual discursive modules of the Grand Tour - had come to an end. If too often in the course of the eighteenth century Italian rejoinders to foreign travellers' writings had resorted to uncritical and rambling apologia - I have already cited the well-known case of Baretti - this no longer happened after the Revolutionary experience, during the Restoration and the incubation of the Risorgimento movement. During the early modern age, or even until late in the eighteenth century, stereotypical identifications drew mainly upon a tradition of literary commonplaces 
associated with the purported character of the inhabitants of the various European countries: the treacherous and corrupt Italian, but also the vain Frenchman, the haughty Spaniard, the stiff and formal Englishman and so on. In the context of the culture of the Enlightenment, this did not corrode the principles of a shared and rationalistic cosmopolitanism, even when it touched upon the Italians' scant morality. With the establishment of Romantic nationalism, and therefore with the greater interest shown and felt in the origins of a people and its particular collective history, distinct from that of any other people, the identificatory stereotypes came to be burdened with a naturalistic implication and a discriminatory significance which could render them far more offensive, irrespective of the attitude, hostile or otherwise, of those who promoted them.

From the Italian point of view, on the eve of the Risorgimento struggle, the malicious or spiteful annotations of the travellers of the Grand Tour, but above all Sismondi's serious and influential reflections, had come to seem a searing and intolerable affront, and the negative image of the unwarlike and corrupt Italian character was no longer evaded but appropriated and overturned by the Italians themselves. In view of the trials of courage and sacrifice which awaited the fighters for the homeland, there was a pressing need for a moral regeneration, starting from a clear re-definition of the respective tasks of the two sexes: fidelity and purity in the mothers and wives of the heroes in the safeguarding of hearth and home, the warlike remasculinisation of the men, who had not only become debased under foreign rule, but also effeminate due to the ignominies of gallantry. ${ }^{32}$

It was, of course, a gigantic propaganda exercise, or rather the wholesale fashioning of an 'imagined community', to use the title of a book by Benedict Anderson that has opened up new horizons in the study of nationalism. ${ }^{33}$ As I have already stated, eighteenth-century Italian cicisbeism was not a sexual practice, but a social institution; besides, there were cicisbei elsewhere, especially in Spain. ${ }^{34}$ In any case, in the context of eighteenth-century 
gallantry, alleged Italian shamelessness was as nothing compared to the unscrupulousness of French libertinage. ${ }^{35}$ The difference lies simply in the fact that since neither the Spanish nor the French were subject to foreign domination, no one dreamt in their case of correlating subservience, corruption and lust. Morality does not exist apart from politics. That said, it is true that the Italian intellectuals and patriots were convinced of the existence of the link between private laxity and public indolence, and elaborated a national ideology around the subject, an ideology which was well expressed by the rhetorical question which, in Foscolo's above-mentioned article 'The Women of Italy', concludes his analysis of the harm wrought by cicisbeism to family life and conjugal dignity: 'Who can expect that men who are indifferent to their own honour will undergo toil or danger for the honour of their country? ${ }^{36}$ Recent research on the Risorgimento by Italian historians has highlighted a crucial aspect of the construction of the Italian national ideology, namely, the ethnic-racial element, or the idea of a nation as a cohesive and united community, existing less by dint of political decisions than through traditional or hereditary, even genetic, components: 'una d'arme, di lingua, d'altare,/di memorie, di sangue e di cor' ('one in arms, language, faith,/memories, blood and heart'). ${ }^{37}$ It is not necessary to agree with every aspect of the historiographical trend to which I have referred - in particular the tendency, when addressing the twin themes Comment: QUERY 8: is layout
of highlighted text in $n 37$ correct? Looks a bit odd at present of Risorgimento and nation, to conflate very different political-ideological positions - in order to recognise the importance of the final outcome. If the nation was not a political choice (an 'everyday plebiscite' according to Ernest Renan's definition), but a natural reality transmitted to the present by immemorial history, then its genetic uniformity acquired an absolute value, which had to be shielded from the uncertain consequences of sexual promiscuity. Hence the development of a vast and insistent patriotic educational programme for men, but above all for Italian women, an educational programme destined to assume - for example, in the three volumes of Caterina Franceschi Ferrucci's Della educazione morale 
della donna italiana (The Moral Education of Italian Women, 1848) - a far more oppressive and more exacting tone than in Canonici Fachini's reply, in which the link with a list of past literary glories, even if women (not men) of letters were involved, had served to maintain a certain naive and old-fashioned air redolent of an ancien régime controversy. ${ }^{38}$

Lady Morgan's travel diary - with all its flaws, errors and even occasional contradictions (which, however, are on the whole of little consequence) - comes on the scene at just the right moment to play its part, thanks to its altogether apposite arguments and its stirring tone, in this great cultural exercise that characterised Italian literature and political consciousness of the first half of the nineteenth century. As a woman, Lady Morgan offered her Italian male and female interlocutors a valuable opportunity to address a problematic, but positive and optimistic, image of their private and public lifestyles in the past and in the present, in a perspective full of promise for the future. Without approaching the breadth of vision, the depth and therefore the importance of her historical-ideological inspiration, Sismondi, she nevertheless developed, with her observations about the morality of the new Italian men and women, an aspect which in her precursor had remained implicit and incomplete: the Causes qui ont changé le caractère des Italiens, depuis l'asservissement de leurs Républiques should by then have been declined in the past tense; circumstances were changing by the day; and this woman 'on the margins', in the positive sense that Natalie Zemon Davis has given to this phrase, was able to view them with unusual perceptiveness and to scrutinise them with admirable open-mindedness.

\footnotetext{
${ }^{1}$ F. de Sanctis, La letteratura italiana nel secolo XIX, L. Blasucci (ed.), vol. 1 (Bari, 1962), 234.
} 
${ }^{2}$ J.-C.-L. Simonde de Sismondi, Storia delle repubbliche italiane dei secoli di mezzo, Italian translation, vol. 16 (Capolago, 1832), 197-200.

${ }^{3}$ Regarding the relationship between Madame de Staël and Sismondi, see the Presentazione by Pierangelo Schiera in the abridged version of Sismondi's work: Storia delle Repubbliche italiane (Turin, 1996), ix-xcvi.

${ }^{4}$ F. Venturi, 'L'Italia fuori d'Italia', in Storia d'Italia, Dal primo Settecento all'Unità (Turin, 1973), 987-1481.

${ }^{5}$ I have gone into greater detail in R. Bizzocchi, 'Sismondi e la morale italiana', in L. Pagliai and F. Sofia, (eds), Sismondi e la nuova Italia (Florence, 2011), 131-43.

${ }^{6}$ For a more detailed treatment of the subject, see R. Bizzocchi, Cicisbei. Morale privata e identità nazionale in Italia (Rome-Bari, 2008). An English translation is to be published by Palgrave Macmillan in 2014.

${ }^{7}$ I have analysed Luisa's diary in detail in R. Bizzocchi, 'Vita sociale, vita privata in un diario femminile tra Sette e Ottocento', Genesis. Rivista della Società Italiana delle Storiche, 3(1) (2004), 125-67.

${ }^{8}$ These descriptions may be found, for example, among the accounts assembled by G. Pitrè, Viaggiatori italiani e stranieri in Sicilia, A. Rigoli (ed.), vol. 1, part 2 (Comiso, 2000), 219, 252 and 335.

${ }^{9}$ I am referring to the article, which I have already mentioned, 'The Women of Italy', of which both the original English text and the Italian translation are in U. Foscolo, Scritti vari di critica storica e letteraria (1817-1827), U. Limentani (ed.) (Florence, 1978), 418-67.

${ }^{10}$ For Manzoni's family life and his relationship with his mother, a study by D. Chiomenti Vassalli, Giulia Beccaria: la madre di Manzoni (Milan, 1956) is of fundamental importance. ${ }^{11}$ F. Confalonieri, Carteggio, G. Gallavresi (ed.) (Milan, 1910-13), vol. 2, 126; G. Capponi, Lettere, A. Carraresi (ed.) (Florence, 1882), vol. 1, 119. 
${ }^{12}$ For a general introduction, including an appraisal of the figure of Lady Morgan, and with considerable attention paid to the ways in which her Irish origins may have affected her perceptions of Italy, the following work is very helpful: D. Abbate Badin, Lady Morgan's Italy: Anglo-Irish Sensibilities and Italian Realities (Bethesda, 2007).

${ }^{13}$ Lady Morgan, Italy (London, 1821), vol. I, 14 ; L'Italie (Paris, 1821), vol. I, 30: 'l'Italie tomba avec Florence'.

${ }^{14}$ Ibid., vol. 1, 17 ('des républiques italiennes’: L'Italie, vol. 1, 37).

${ }^{15}$ Ibid., vol. 2, 258 ('anomalie dans la société humaine': L'Italie, vol. 3, 402).

${ }^{16}$ Ibid., vol. 2, 265 ('malpropres et superstitieux comme des faquirs indiens, végètent dans des niches de leurs fastueux palais': L'Italie, vol. 3, 418 - note that 'fatuous' becomes, in French, 'superstitious', while the harsh and deeply prejorative term 'sty' is avoided).

${ }^{17}$ See, for example, J. Fellheimer, 'The "Subtlety” of the Italians', English Miscellany, 12 (1961), 21-31.

${ }^{18}$ Morgan, Italy, vol. 2, 377 ('Dans le temps où l'auteur de ces pages était trop jeune et trop ignorante pour s'intéresser aux transactions politiques d'aucun pays, elle a souvent écouté avec ravissement lady Hamilton décrivant les beautés des rivages de Naples, et la position où elle se trouvait quand elle était assise pendant le calme d'une belle nuit éclairée par la lune, à la droite du héros du Nil sur le vaisseau amiral, chantant sur les vagues de la Méditerranée l'hymne National Rule Britannia, répété en choeur par tout l'équipage; mais si elle avait su alors que tandis que la sirène chantait, des milliers de personnes périssaient, et que ces nuits de fêtes terminaient des jours de sang, elle aurait fui la présence de l'enchanteresse, et l'aurait abhorrée comme elle abhorre maintenant sa mémoire, surtout depuis son séjour à Naples: ceux qui se réjouissent de la défaite des Napolitains en 1821, devraient se rappeler le sort de ceux qui ont été livrés à la clémence royale en 1799': L'Italie, vol. 4, 222-23). 
${ }^{19}$ Ibid., vol. 2, 140 ('dans ce court espace de temps il a peut-être disséminé plus de vérités philosophiques et littéraires qu'on n'en pourrait trouver dans aucun des journaux, ses contemporains, établis depuis la Restauration': L'Italie, vol. 3, 146).

${ }^{20}$ Ibid., vol. 1, 161 ('L'abolition de toutes les institutions monastiques, la réforme des universités, l'établissement des écoles pour les filles, la conscription et les grandes convulsions politiques des derniers vingt-cinq ans ont donné à la génération naissante un nouveau caractère, et tiré entre les pères et les enfans une ligne de démarcation qu'il est impossible d'effacer': L'Italie, vol. 1, 352).

${ }^{21}$ Ibid., vol. 2, 92 ('une distance morale plus grande que la seule différence d'âge ne l'aurait établie': L'Italie, vol. 3, 42).

${ }^{22}$ Ibid., vol. 2, 93 ('l'usage n'en est-il pas général': L'Italie, vol. 3, 45).

${ }^{23}$ Ibid., vol. 1, 161-62 (L'Italie, vol. 1, 352).

${ }^{24}$ Ibid., vol. 1, 252 ('point de sigisbé, point de patito, point de confesseur'. 'On voit encore, cependant, parmi la vieille aristocratie, quelques monumens du vieux patito génois dans les ci-devant jolis garçons de la veglia di quaranta, qui continuent à porter le livre de prières, à présenter le bouquet d'usage à leur dame et maîtresse, et à l'accompagner le matin à l'église de l'Annunciata, et le soir à la promenade de Strada Nuova; mais l'éducation des jésuites et des inquisiteurs, qui laissait la jeunesse génoise ignorante et faible, et la jetait dans le jeu ou la galanterie, les seules ressources et les seules occupations qui pussent lui convenir, a depuis longtemps cessé d'exister, et on ne l'a pas encore rétablie': L'Italie, vol. 2, 34-36).

${ }^{25}$ Regarding the Sharp-Baretti polemic, see R. Bizzocchi, 'Difendere gli Italiani. Londra, primi mesi del 1768', in . Luzzatto and G. Pedullà (eds), Atlante della Letteratura Italiana, vol. 2, Dalla Controriforma alla Restaurazione (Turin, 2011), 710-15. 
${ }^{26}$ Morgan, Italy, vol. 2, 388 ('En prenant la population napolitaine dans son ensemble, elle possédait assez de vertus et de talens pour soutenir un régime constitutionnel, si l'injuste intervention des étrangers ne s'y était pas opposée': L'Italie, vol. 4, 245-46).

${ }^{27}$ Ibid., vol. 2, 406 ('Il unit leur belles qualités à des talens politiques et littéraires très remarquables; et ses vertus domestiques sont à l'unisson de ses principes patriotiques': L'Italie, vol. 4, 284).

${ }^{28}$ Ibid., vol. 2, 406-07 ('Telles sont les scènes de vertu privée qu'on trouve à Naples, résultant (on ne saurait trop le répéter) de ces institutions qui ont aboli les ordres monastiques, et fermé les cellules où la jeunesse était imprisonnée pour obéir à un système politique et religieux, qui obligeait les parens à briser les liens les plus sacrés de la nature, à sacrifier leurs enfans à l'ambition ou à l'avarice ... Puissent les horreurs de la réaction de ce moment, s'arrêter aux portes qui renferment des sentimens si nobles et si doux; que les Acton et les Vanni du jour, Ruffo ou Canosa, ne traînent point au tribunal et à l'échafaud les membres de ces illustres familles qui se sont encore placées dans les rangs du patriotisme pour conserver à leur pays les biens qu'il avait nouvellement acquis, et le sauver des anciens maux en dépit de la ligue de ceux pour lesquels la vertu n'est qu'un nom!': L'Italie, vol. 4, 284-85).

${ }^{29}$ J. Belanger, Critical Receptions: Sydney Owenson, Lady Morgan (Bethesda, 2007).

${ }^{30}$ D. Abbate Badin, 'Lady Morgan and the Italian Female Other', in S. Albertazzi and C. Pelliconi (eds), Cross-Cultural Encounters: Literary Perspectives (Rome, 2005), 32-42; F. Sinopoli, 'Da Corinne alle "altre”: per un confronto tra Lady Morgan e Ginevra Canonici Fachini', Dimensioni e problemi della ricerca storica, 1 (2010), 31-44; Tatiana Crivelli, 'Deh, non opinate, o Signora, così spregevolmente di noi: l'Italia illustrata dalle Italiane', in altrelettere, 29 February 2012, DOI: 10.5903/al_nzh-1. 
${ }^{31}$ G. Canonici Fachini, Prospetto biografico delle donne italiane rinomate in letteratura dal secolo decimoquarto fino a' giorni nostri ... Con una Risposta a Lady Morgan risguardante alcune accuse da lei date alle donne italiane nella sua opera l'Italie (Venice, 1824), 21. ${ }^{32}$ An extensive treatment and illustration of this subject is to be found in the article by S. Patriarca, 'Indolence and Regeneration: Tropes and Tensions of Risorgimento Patriotism', American Historical Review, 110 (2005), 380-408.

${ }^{33}$ Benedict Anderson, Imagined Communities: Reflections on the Origin and Spread of Nationalism, 2nd edn (London, 1991).

${ }^{34}$ For the sceptics: Carmen Martín Gaite, Usos amorosos del dieciocho en España, 2nd edn (Barcelona, 1972).

${ }^{35}$ I will confine myself to citing Michel Delon, Le savoir-vivre libertin, (Paris, 2000).

${ }^{36}$ Foscolo, Scritti vari di critica storica e letteraria, 466.

${ }^{37}$ These lines are from Manzoni's Marzo 1821. A summary of the historiographical trend to which I have referred in the text is to be found in Il Risorgimento, Annali 22 of the Storia d'Italia, edited by Alberto Mario Banti and Paul Ginsborg (Turin, 2007).

${ }^{38}$ Caterina Franceschi Ferrucci, Della educazione morale della donna italiana libri tre (Turin, 1848). 